\title{
EFEKTIVITAS METODE SOROGAN BERBANTUAN TUTOR SEBAYA TERHADAP PEMAHAMAN KONSEP MATEMATIKA
}

\author{
Ahmat Wakit ${ }^{1)}$ \\ ${ }^{1)}$ Universitas Islam Nahdlatul Ulama (UNISNU) Jepara, Jl. Taman Siswa (Pekeng) \\ Tahunan, Jepara
}

Email : wak_ahmat@yahoo.com

\begin{abstract}
Mathematics learning with sorogan method assisted by peer tutor is learning where students do the exercises in front of the teacher directly, but the students have studied the exercices with their peers before. The aim of this research was to determine the effectiveness of mathematics teaching with sorogan method assisted by peer tutor. The results of this study was mathematics learning with sorogan method assisted peer tutors was effective and there was an increase of understanding the concept in experimental class.
\end{abstract}

Keywords : sorogan, peer tutor, understanding the concept

\section{PENDAHULUAN}

Standar isi mata pelajaran matematika tahun 2006 dinyatakan bahwa mata pelajaran matematika dipelajari dengan tujuan agar peserta didik memiliki beberapa kemampuan, yaitu; kemampuan memahami konsep matematika, menggunakan penalaran, memecahkan masalah, mengomunikasikan gagasan, dan memiliki sikap menghargai kegunaan matematika dalam kehidupan (Wardani, 2010:10). Pemahaman konsep matematika sangat di perlukan dalam pembelajaran matematika, pemahaman konsep adalah dasar dari pengetahuan ilmu matematika dimana nantinya pengetahuan yang dikuasai dapat digunakan untuk menyelesaikan pemecahan masalah dalam kehidupan sehari-hari dan membantu meningkatkan penalaran peserta didik.

Hasil penelitian awal menunjukkan bahwa pemahaman konsep peserta didik masih rendah. Ada beberapa faktor yang menyebabkan pemahaman konsep mahasiswa rendah, antara lain kurangnya kesadaran peserta didik belajar matematika, ketergantungan peserta didik pada teman yang dianggap lebih pandai, lebih mementingkan nilai dari pada pemahaman konsep, artinya mahasiswa akan melakukan berbagai cara untuk mendapatkan nilai bagus dengan instan seperti bekerja sama 
saat ujian, mencontek dengan memanfaatkan smartphone dll. Peserta didik banyak yang berfikir bahwa jika ada tugas, peserta didik tidak perlu repot mengerjakan karena sudah terbiasa berfikir instan salah satunya dengan menulis jawaban teman tanpa mengetahui apa yang ditulis (asal tulis).

Pemilihan metode pembelajaran yang tepat dalam proses pembelajaran sangat berpengaruh pada keberhasilan peserta didik. Banyak metode dan model pembelajaran yang terbukti dapat meningkatkan kemampuan matematika peserta didik, baik kemampuan memahami konsep, pemecahan masalah maupun penalaran matematika. Metode pembelajaran yang populer di kalangan pesantren salaf adalah metode sorogan, metode sorogan ini mengharuskan santri (peserta didik) untuk belajar sendiri atau belajar dengan temannya dan sistem belajar sorogan membentuk peserta didik untuk tidak bergantung pada teman, karena sistem pembelajarannya langsung dipraktekkan di depan kiai (ustadz/guru). Metode sorogan juga dikenal dengan istilah independent learning, pembelajaran menggunakan metode sorogan adalah memfokuskan pada belajar mandiri peserta didik/pembelajaran individu (Meyer, 2010:12).

\section{Pelaksanaan}

proses pembelajaran matematika dengan sistem belajar individu sangat sulit dilakukan dan dipraktekkan oleh peserta didik, untuk mengatasi permasalahan ini diperlukan bantuan teman sejawat (tutor sebaya) dalam memahami konsep matematika. Tsuei (2014) dan Grubbs, N \& Boes, S.B. (2009) menjelaskan bantuan rekan sebaya dapat membimbing dan memfasilitasi komunikasi antara pesera didik dan pemahaman konsep matematika dalam kegiatan online. Muhammad (2011) menambahkan bahwa tutor sebaya adalah peserta didik yang ditunjuk atau ditugaskan membantu teman-temannya yang mengalami kesulitan belajar, karena hubungan teman umumnya lebih dekat dibandingkan hubungan guru dengan peserta didik. Menurut Nurudin (2009: 9-10) dan Arjanggi (2010:96) pembelajaran melalui tutor teman sebaya efektif dalam meningkatkan belajar berdasar regulasi-diri pada mahasiswa. Pembelajaran dengan metode tutor sebaya juga dapat menjadikan siswa menjadi sadar akan kemampuan mereka sendiri dan memungkinkan mereka melakukan perbaikan (Flores, 2013). Romano (2010) menegaskan bahwa bekerja dengan rekan-rekan menyebabkan pemahaman yang lebih besar.

Melihat kesuksesan di atas peneliti berasumsi bahwa metode ini dapat menyelesaikan masalah yang ada sehingga peneliti ingin mengetahui sejauh mana pembelajaran matematika dengan metode sorogan yang dipadukan dengan bantuan tutor sebaya khususnya dalam perkuliahan matematika pada program studi Teknik Informatika Fakultas Sains dan 
Teknologi Universitas Islam Nahdlatul Ulama (UNISNU) Jepara, dengan harapan bahwa dengan menerapkan metode sorogan berbantuan tutor sebaya dapat meningkatkan pemahaman konsep mahasiswa. Rumusan masalah pada penelitian ini adalah apakah penerapan metode sorogan berbantuan tutor sebaya pada perkuliahan matematika efektif?

Pelaksanaan pembelajaran matematika dengan metode sorogan berbantuan tutor sebaya dalam penelitian ini memiliki beberapa tahapan. Tahapan pertama adalah persiapan, pada tahapan ini pengajar/dosen menyiapkan bahan perkuliahan yang meliputi materi dan soal, pada pertemuan pertama dosen menjelaskan sistem perkuliahan dengan metode sorogan berbantuan tutor sebaya. Pemilihan teman sebagai tutor sebaya, tidak ditentukan oleh pengajar artinya peserta didik bebas memilih siapa yang menjadi tutor sebaya mereka, siapa yang dianggap akrab, dekat serta mampu menjadi tutor sebaya.

Tahapan selanjutnya adalah tahap pelaksanaan, pada tahapan ini dosen menjelaskan materi dengan contoh sederhana, selanjutnya dosen memberikan soal-soal latihan yang harus dikerjakan oleh mahasiswa langsung di depan dosen. Proses sorogan yang dimaksudkan dalam penelitian ini adalah peserta didik/mahasiswa mengerjakan soalsoal latihan langsung di depan dosen satu persatu, jika dalam menyelesaikan persoalan ada kekeliruan, dosen mengingatkan dan membenarkan dengan harapan pada pertemuan/ sorogan selanjutnya, tidak mengulangi kesalahan yang sama. Sebelum mahasiswa mengerjakan soal di depan dosen, mahasiswa boleh mempelajari materi dan soal-soal latihan dengan teman tutor sebaya yang mereka pilih. Proses sorogan tidak hanya dilakukan saat perkuliahan berlangsung, mahasiswa diperbolehkan sorogan diluar jam perkuliahan.

Tahap terakhir adalah tahap monitoring dan refleksi, pada tahapan ini dosen mengoreksi jawaban mahasiswa saat melaksanakan sorogan, memberikan masukan dan arahan untuk perbaikan pada pertemuan/sorogan selanjutnya. Tahap terakhir ini tidak bisa dipisahkan dengan tahap pelaksanaan karena tahapan ini dilaksanakan saat/setelah pelaksanaan sorogan.

\section{LANDASAN/KAJIAN TEORI}

Metode sorogan adalah metode pembelajaran yang sering digunakan dalam dunia pesantren salaf. Kata sorogan sebenarnya berasal dari bahasa Jawa (sorog) yang berarti menyodorkan kitab kehadapan kyai/ustadz. Menurut Zarkasyi (2005:73) metode sorogan adalah bentuk pengajaran dimana peserta didik satu persatu dating menghadap guru/kyai/ustadz dengan membawa materi tertentu. Menurut Arjanggi (2010:94) metode tutor sebaya adalah suatu metode pembelajaran yang dilakukan dengan cara 
memberdayakan peserta didik yang memiliki daya serap yang tinggi untuk menjadi tutor bagi teman-temannya. Menurut Hasbullah (2008:145), Sumardi (2012:285) dan Wahyu Utomo dalam (Arif, 2002:150) metode sorogan adalah metode pembelajaran dengan cara para santri maju satu persatu untuk menyodorkan kitabnya dan berhadapan langsung dengan seorang guru atau kyai dan terjadi interaksi di antara keduanya dalam proses pengajarannya.

Pembelajaran matematika dengan metode sorogan berbantuan tutor sebaya yang dimaksudkan pada penelitian ini adalah mahasiswa menghadap dosen satu persatu bergantian untuk mengerjakan soal latihan yang sudah diberikan dan jika ada kekeliruan dalam mengerjakan dosen langsung membenarkan atau memberikan pertanyaan agar mahasiswa memahami letak kesalahannya. Pada sorogan berikutnya diharapkan kesalahan yang sama tidak diulangi. Mahasiswa dapat mempelajari soal yang akan dikerjakan terlebih dahulu dengan bimbingan tutor sebayanya. Temuan dalam penelitian Nurudin (2009:9), Arjanggi (2010:96) dan Romano (2010) menunjukkan bahwa pembelajaran melalui tutor sebaya efektif dalam meningkatkan belajar berdasar regulasi diri pada mahasiswa. Penelitian Flores (2013) juga menyimpulkan bahwa pembelajaran dengan metode tutor sebaya dapat menjadikan peserta didik menjadi sadar akan kemampuan mereka sendiri dan memungkinkan mereka melakukan perbaikan.

\section{METODE PENELITIAN}

\section{Jenis Penelitian}

Jenis penelitian ini adalah true experimental. Menurut Arikunto (2010:86) penelitian true experimental dengan menggunakan control group pre-test post-test design karena disamping kelompok eksperimen, ada kelompok kontrol sebagai pembanding.

\section{Waktu dan Tempat Penelitian}

Penelitian ini dilaksanakan di Universitas Islam Nahdlatul Ulama (UNISNU) Jepara. Waktu pelaksanaan penelitian di semester gasal 2015/2016.

\section{Populasi dan Sampel}

Populasi pada penelitian ini adalah seluruh mahasiswa program studi Teknik Informatika yang mengambil matakuliah matematika, teknik pengambilan sampel mengunakan cluster random sampling. Sampel dari penelitian ini adalah mahasiswa teknik informatika UNISNU Jepara semester awal kelas DA dan kelas DB.

\section{Prosedur}

Langkah pertama pelaksanaan penelitian dilakukan adalah dengan pengelompokkan siswa secara acak yaitu kelas DA sebagai kontrol dan kelas DB sebagai kelas eksperimen, yang kemudian diberi perlakuan yang berbeda. Kelas kontrol dengan perlakuan biasa yaitu pembelajaran 
ekspositori dan kelas eksperimen diberi perlakuan khusus yaitu pembelajaran dengan metode sorogan berbantuan tutor sebaya. Sebelum dan sesudah diberi perlakuan, kedua kelas diberi tes. Hasil dari tes digunakan untuk mengetahui perbedaan dan peningkatan pemahaman konsep peserta didik kelas eksperimen dan kelas kontrol.

\section{Data, Intrumen, dan Teknik Pengumpulan Data}

Data pada penelitian ini adalah data keterampilan proses dan data hasil tes. Instrumen yang digunakan dalam pengumpulan data adalah lembar observasi dan soal tes. Teknik pengumpulan data pada penelitian ini adalah observasi dan tes. Observasi digunakan untuk mengetahui keterampilan proses mahasiswa selama proses pembelajaran dan tes digunakan untuk mengetahui pemahaman konsep mahasiswa. Tes diberikan awal dan di akhir pertemuan dalam bentuk soal uraian.

\section{Teknik Analisis Data}

Teknik analisis data pada penelitian ini meliputi uji prasyarat dan analisis keefektivan. Uji prasyarat meliputi uji normalitas dan uji homogenitas, uji prasyarat ini menggunakan bantuan program SPSS.

\section{Analisis keefektivan} pembelajaran dengan metode sorogan berbantuan tutor sebaya meliputi uji ketuntasan menggunakan uji t, uji banding menggunakan independent sample t-test, uji beda proporsi ketuntasan, uji pengaruh (regresi) keterampilan proses terhadap pemahaman konsep matematika menggunakan analisis regresi dan uji peningkatan.

\section{1) Uji Ketuntasan}

Uji ketuntasan hasil belajar digunakan untuk mengetahui ketercapaian ketuntasan klasikal mahasiswa pada materi integral dibandingkan dengan Kriteria Ketuntasan Minimal yang ditetapkan peneliti yang besarnya 70 dengan ketuntasan klasikal $75 \%$ dan ketercapaian ketuntasan rata-rata kelas eksperimen.

2) Uji Banding

Uji banding digunakan untuk mengetahui perbedaan rata-rata nilai tes akhir mahasiswa kelas eksperimen dengan mahasiswa kelas kontrol.

\section{3) Uji Beda Proporsi}

Uji beda proporsi digunakan untuk membandingkan proporsi ketuntasan hasil belajar mahasiswa kelas eksperimen dengan mahasiswa kelas kontrol.

\section{4) Uji Pengaruh}

Uji pengaruh digunakan untuk mengetahui pengaruh variabel independen yaitu keterampilan proses (X) terhadap variabel dependen yaitu pemahaman konsep (Y). Uji pengaruh ini digunakan uji regresi sederhana. Asumsi dari analisis regresi adalah uji keberartian dan uji linearitas. 


\section{5) Uji Peningkatan}

Peningkatan pemahaman

konsep mahasiswa pada awal sebelum diberi perlakuan (pretest) dan setelah diberi perlakuan (posttest) pada kelas yang diajar dengan metode sorogan berbantuan tutor sebaya. Rumus yang digunakan adalah

$$
t=\frac{\bar{x}_{1}-\bar{x}_{2}}{\sqrt{\left(\frac{s_{1}^{2}}{n_{1}}+\frac{s_{2}^{2}}{n_{2}}\right)}}
$$

Keterangan :

$\bar{x}_{1}=$ rataan hasil belajar mahasiswa

pada kelas eksperimen,

$\bar{x}_{2}=$ rataan hasil belajar mahasiswa

pada kelas kontrol,

$s_{1}=$ simpangan baku kelas eksperimen,

$s_{2}=$ simpangan baku kelas kontrol,

$n_{1}=$ banyak siswa kelas eksperimen,

$n_{2}=$ banyak siswa kelas kontrol.

(Sudjana, 2010:243).

\section{HASIL PENELITIAN DAN PEMBAHASAN}

Penelitian ini dilaksanakan di dua kelas yaitu kelas eksperimen dan kelas kontrol. Setelah kedua kelas diberi perlakuan, kemudian diberikan tes akhir. Data dari tes akhir dianalisis untuk mengetahui efektivitas pembelajaran matematika dengan metode sorogan berbantuan tutor sebaya.

Hasil penelitian ini menunjukan bahwa pembelajaran matematika dengan metode sorogan berbantuan tutor sebaya efektif, karena memenuhi beberapa hal yaitu: 1) pemahaman konsep peserta didik yang diajar menggunakan metode sorogan berbantuan tutor sebaya mencapai ketuntasan klasikal, 2) pemahaman konsep peserta didik yang diajar menggunakan metode sorogan berbantuan tutor sebaya lebih baik dari pada peserta didik yang diajar dengan metode ekspositori, 3) proporsi ketuntasan pemahaman konsep peserta didik yang diajar menggunakan metode sorogan berbantuan tutor sebaya lebih baik dari pada peserta didik yang diajar dengan metode ekspositori, 4) ada pengaruh dari keterampilan proses terhadap pemahaman konsep sebesar 29,7\%, dan 5) adanya peningkatan pemahaman konsep peserta didik yang diajar menggunakan metode sorogan berbantuan tutor sebaya.

Pembahasan hasil penelitian terurai pada masing-masing analisis uji yang digunakan dalam penelitian ini yaitu:

\section{Analisis Uji Ketuntasan}

Uji ketuntasan rata-rata kelas digunakan uji satu pihak. Kriteria pengambilan $H_{0}$ ditolak jika $t_{\text {hitung }} \geq$ $t_{\text {tabel }}$ dengan $d k=(n-1)$ dan taraf signifikan yang digunakan $5 \%$. Perhitungan $t_{\text {hitung }}$ pada penelitian ini menggunakan program SPSS.

Tabel 1. Output SPSS OneSample Test menunjukkan $t_{\text {hitung }}=$ 3,633 dan $t_{\text {tabel }}$ dengan $d k=31$ dan taraf signifikan $5 \%=1,695$. Karena $t_{\text {hitung }}>t_{\text {tabel }}$, maka $H_{0}$ ditolak dan $H_{1}$ diterima. Dapat disimpulkan bahwa rata-rata pemahaman konsep 
peserta didik kelas eksperimen lebih dari 70.

Uji ketuntasan klasikal digunakan untuk mengetahui apakah lebih dari $75 \%$ siswa mencapai nilai minimal 70 dalam tes pemahaman konsep. Nilai hasil tes pemahaman konsep peserta didik kelas eksperimen kemudian diuji ketuntasan klasikalnya. Didapatkan nilai $z_{\text {hitung }}=1,69>z_{\text {tabel }}=$ 1,64. Karena $\mathrm{Z}_{\text {hitung }}>\mathrm{z}_{(0,5-0,05)}$ maka $\mathrm{H}_{0}$ ditolak artinya $\mathrm{H}_{1}$ diterima. Dapat disimpulkan bahwa lebih dari $75 \%$ pemahaman konsep peserta didik kelas eksperimen mencapai atau di atas 70 .

Tabel 1. Output SPSS One-Sample Test

Test Value $=70$

\begin{tabular}{|c|c|c|c|c|}
\hline & & \multirow{2}{*}{$\begin{array}{l}\text { Sig. }(2- \\
\text { tailed })\end{array}$} & \multirow{2}{*}{$\begin{array}{c}\text { Mean } \\
\text { Difference }\end{array}$} & $\begin{array}{c}95 \% \text { Confidence Interval of } \\
\text { the Difference }\end{array}$ \\
\hline & & & & Lower \\
\hline man_konsep & 3.633 & 31 & 11.96875 & 5.2496 \\
\hline \multicolumn{5}{|c|}{$\begin{array}{l}\text { 1,67. Karena } t_{\text {hitung }}>t_{\text {tabel }} \text {, maka } \mathrm{H}_{0} \\
\text { ditolak dan } \mathrm{H}_{1} \text { diterima. Dapat } \\
\text { disimpulkan bahwa rata-rata } \\
\text { pemahaman konsep peserta didik kelas } \\
\text { eksperimen lebih baik dari rata-rata } \\
\text { pemahaman konsep kelas kontrol. }\end{array}$} \\
\hline
\end{tabular}

SPSS 16 diperoleh nilai $t_{\text {hitung }}$ sebesar

2,665. Sedangkan nilai $t_{\text {tabel }}$ sebesar

Tabel 2. Output SPSS Independent Samples Test

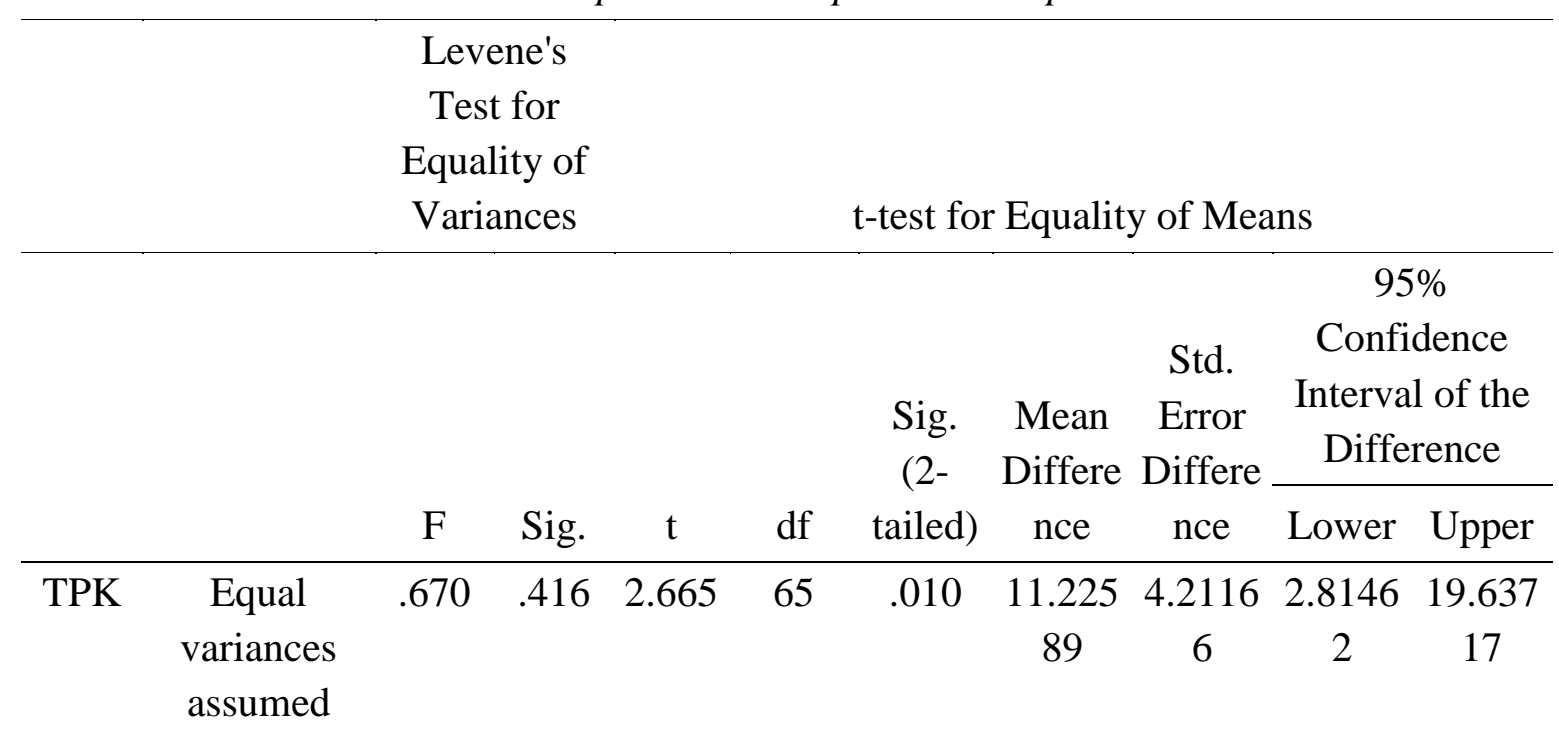


Tabel 2. Output SPSS Independent Samples Test

\begin{tabular}{|c|c|c|c|c|c|c|c|c|c|c|}
\hline & & \multicolumn{2}{|c|}{$\begin{array}{l}\text { Levene's } \\
\text { Test for } \\
\text { Equality of } \\
\text { Variances }\end{array}$} & \multicolumn{7}{|c|}{ t-test for Equality of Means } \\
\hline & & \multirow[b]{2}{*}{$\mathrm{F}$} & \multirow[b]{2}{*}{ Sig. } & \multirow[b]{2}{*}{$\mathrm{t}$} & \multirow[b]{2}{*}{ df } & \multirow{2}{*}{$\begin{array}{c}\text { Sig. } \\
(2- \\
\text { tailed) }\end{array}$} & \multirow{2}{*}{$\begin{array}{l}\text { Mean } \\
\text { Differe } \\
\text { nce }\end{array}$} & \multirow{2}{*}{$\begin{array}{c}\text { Std. } \\
\text { Error } \\
\text { Differe } \\
\text { nce }\end{array}$} & $\begin{array}{r}95 \\
\text { Confi } \\
\text { Interva } \\
\text { Diffe } \\
\end{array}$ & $\begin{array}{l}\% \% \\
\text { idence } \\
l \text { of the } \\
\text { rence }\end{array}$ \\
\hline & & & & & & & & & Lower & Upper \\
\hline TPK & $\begin{array}{c}\text { Equal } \\
\text { variances } \\
\text { assumed }\end{array}$ & .670 & .416 & 2.665 & 65 & .010 & $\begin{array}{c}11.225 \\
89\end{array}$ & $\begin{array}{c}4.2116 \\
6\end{array}$ & $\begin{array}{c}2.8146 \\
2\end{array}$ & $\begin{array}{c}19.637 \\
17\end{array}$ \\
\hline & $\begin{array}{c}\text { Equal } \\
\text { variances not } \\
\text { assumed }\end{array}$ & & & 2.646 & 51.112 & .010 & $\begin{array}{c}11.225 \\
89\end{array}$ & $\begin{array}{c}4.2429 \\
1\end{array}$ & $\begin{array}{c}2.7419 \\
9\end{array}$ & $\begin{array}{c}19.709 \\
80\end{array}$ \\
\hline
\end{tabular}

\section{Analisis Uji Beda Proporsi}

Kriteria pengambilan keputusan $\mathrm{H}_{0}$ ditolak jika $z_{\text {hitung }} \geq$ $z_{0,5-\alpha}$. Perhitungan menggunakan rumus $\mathrm{z}$ diperoleh nilai $z_{\text {hitung }}$ sebesar 2,968. Sedangkan $z_{\text {tabel }}=z_{(0,5-0,05)}=$ $z_{0,475}=1,64$. Karena $z_{\text {hitung }}>z_{\text {tabel }}$, maka $\mathrm{H}_{0}$ ditolak dan $\mathrm{H}_{1}$ diterima. Dapat disimpulkan bahwa proporsi ketuntasan peserta didik kelas eksperimen lebih dari proporsi ketuntasan peserta didik kelas kontrol.

\section{Analisis Uji Pengaruh}

a. Uji linieritas

Pada Tabel 3. Output SPSS ANOVA diperoleh nilai jumlah kuadrat deviasi (sum of squares untuk regression) adalah 3199,162; residual adalah 7567,807 ; dan totalnya adalah
10766,969. Mean square untuk regression adalah 3199,162 dan residual adalah 252,260. $\quad \mathrm{F}_{\text {hitung }}=$ 12,682 $>\mathrm{F}_{\text {tabel }(0,05: 2: 30)}=3,32$ dan nilai $\operatorname{sig}=0,001<0,05(5 \%)$, artinya $\mathrm{H}_{0}$ ditolak dan $\mathrm{H}_{1}$ diterima.

Jadi dapat disimpulkan bahwa terdapat hubungan linear antara keterampilan proses (X) dengan pemahaman konsep (Y). 
Tabel 3. Outpus SPSS ANOVA

\begin{tabular}{rrrrrrr}
\hline & Model & Sum of Squares & df & Mean Square & F & \multicolumn{1}{c}{ Sig. } \\
\hline 1 & Regression & 3199.162 & 1 & 3199.162 & 12.682 & $.001^{\mathrm{a}}$ \\
& Residual & 7567.807 & 30 & 252.260 & & \\
& Total & 10766.969 & 31 & & & \\
\hline
\end{tabular}

a. Predictors: (Constant), $\mathrm{X}$

b. Dependent Variable: Y

b. Uji keberartian

Hasil uji keberartian terurai pada Tabel 4. Output SPSS Coefficients $^{a}$ dan diperoleh nilai sig untuk $\mathrm{X}=0,001<0,05$ jadi $\mathrm{H}_{0}$ ditolak dan menerima $\mathrm{H}_{1}$, artinya keragaman nilai $\mathrm{Y}$ dapat dijelaskan oleh keragaman nilai $X$. terhadap

Persamaan regresi untuk $\mathrm{X}$ $\mathrm{Y}$ adalah $\hat{y}=46,261+0,467 X$ dengan melihat Tabel 5. diperolah nilai $R$ square atau $R^{2}=0,297=29,7 \%$. Hal ini menunjukkan bahwa variabel $\mathrm{X}$ mempunyai kontribusi terhadap $\mathrm{Y}$ sebesar $29,7 \%$.

Tabel 4. Output SPSS Coefficients ${ }^{a}$

\begin{tabular}{|c|c|c|c|c|c|c|}
\hline & \multirow[b]{2}{*}{ Model } & \multicolumn{2}{|c|}{$\begin{array}{c}\text { Unstandardized } \\
\text { Coefficients }\end{array}$} & \multirow{2}{*}{$\begin{array}{c}\text { Standardized } \\
\text { Coefficients }\end{array}$} & \multirow[b]{2}{*}{$\mathrm{T}$} & \multirow[b]{2}{*}{ Sig. } \\
\hline & & B & Std. Error & & & \\
\hline \multirow[t]{2}{*}{1} & (Constant) & 46.261 & 10.413 & & 4.443 & .000 \\
\hline & $X$ & .467 & .131 & .545 & 3.561 & .001 \\
\hline
\end{tabular}

a. Dependent Variable: Y

Tabel 5. Output SPSS Model Summary

\begin{tabular}{crrrr}
\hline Model & R & R Square & \multicolumn{1}{c}{$\begin{array}{c}\text { Adjusted R } \\
\text { Square }\end{array}$} & $\begin{array}{l}\text { Std. Error of } \\
\text { the Estimate }\end{array}$ \\
\hline 1 & $.545^{\mathrm{a}}$ & .297 & .274 & 15.88270 \\
\hline
\end{tabular}

a. Predictors: (Constant), $\mathrm{x}$

\section{Analisis Uji Peningkatan}

Kriteria pengujiannya adalah $H_{0}$ diterima jika $t_{\text {hitung }}<t_{\text {tabel }}$ dengan $d k=n_{1}+n_{2}-2$ dan taraf signifikansi $5 \%$. Hasil uji peningkatan menunjukkan nilai $t_{\text {hitung }}$ sebesar 2,92. Sedangkan nilai $t_{\text {tabel }}$ diperoleh 1,70. Karena $t_{\text {hitung }}>t_{\text {tabel }}$, maka $\mathrm{H}_{0}$ ditolak dan $\mathrm{H}_{1}$ diterima. Dapat disimpulkan rataan selisih pemahaman konsep 
peserta didik sesudah diajar menggunakan metode sorogan berbantuan tutor sebaya lebih baik dari rataan pemahaman konsep peserta didik sebelum diajar menggunakan metode sorogan berbantuan tutor sebaya.

\section{SIMPULAN DAN SARAN}

Berdasarkan analisis hasil penelitian dapat disimpulkan bahwa pembelajaran dengan metode sorogan berbantuan tutor sebaya efektif. Pembelajaran dengan metode sorogan berbantuan tutor sebaya dapat meningkatkan pemahaman konsep matematika dan pembelajaran dengan metode ini peserta didik cenderung rileks dalam proses pembelajaran matematika sehingga menyebabkan suatu kondisi pembelajaran yang menyenangkan.

Metode sorogan berbantuan tutor sebaya sangat efektif jika diterapkan pada kelas dengan peserta didik sedikit, sedangkan pada kelas dengan peserta didik banyak proses sorogan akan membutuhkan banyak waktu. Kelemahan metode sorogan berbantuan tutor sebaya yaitu guru harus meluangkan banyak waktu untuk proses sorogan karena dalam pelaksanaan sorogan membutuhkan waktu yang sangat lama sehingga pelaksanakan sorogan tidak harus selalu di dalam kelas, namun bisa di luar kelas dan di luar waktu pembelajaran.

\section{DAFTAR PUSTAKA}

Arif, A. (2002). Pengantar Ilmu dan Metodologi Pendidikan Islam. Jakarta: Ciputat Press.

Arikunto, S. (2010). Prosedur Penelitian Suatu Pendekatan

Praktik. Jakarta: Rineka Cipta.

Arjanggi, R \& Suprihatin, T. (2010).

Metode Pembelajaran Tutor

Sebaya Meningkatkan Hasil

Belajar Berdasar Regulasi Diri.

Makara Sosial Humaniora. Vol.

14 No. 2 Hal. 91-97.

Flores, M. and Duran, D. (2013).

Effects of Peer Tutoring on

Reading Self Concept.

International Journal of

Educational Psychology. Vol. 2

No. 3.

Grubbs, N \& Boes, S.B. (2009). The

Effects of the Peer Tutoring

Program: An Action Research

Study of the Effectiveness of the

Peer Tutoring Program at One

Suburban Middle School.

Georgia School Counselors

Association journal. Volume 16,

No. 1, 21-31.

Hasbullah. (2008). Sejarah Pendidikan

Islam di Indonesia: Lintasan

Sejarah Pertumbuhan dan

Perkembangannya. Jakarta: PT.

Raja Grafindo Persada.

Meyer, W.R. (2010). Independent Learning: A Literature and $A$

New Project. Makalah di sampaikan di British Educational Research Association Annual Conference, University of Warwick 1-4 September 2010.

Romano, P. \& Walker, J. (2010). Bio Buddies: Peer Tutoring as an 
Instructional Strategy. NERA

Conference Proceedings 2010.

Paper 3.

Sudjana. (2010). Metoda Statistika.

Bandung: Alfa Beta.

Sugiyono. (2013). MetodePenelitian

Pendidikan

(Pendekatan

Kuantitatif, Kualitatif, dan

$R \& D)$. Bandung: Alfabeta.

Sumardi, Kamim. (2012). Potret

Pendidikan Karakter di Pondok

Pesantren Salafiah. Jurnal

Pendidikan Karakter, Vol, 2. No.

3. Hal 280-292.

The Meadows Center for Preventing

Educational Risk. (2010).

Strategies and Activities for

Independent Learning (SAIL).

Mathematics Institute for

Learning Disabilities and
Difficulties University of Texas

System/Texas Education Agency. Tsuei, M. (2014). Mathematics Synchronous Peer Tutoring System for Students with Learning Disabilities. Educational Technology \& Society, 17 (1), 115-127.

Wardhani, S. (2010). Implikasi Karakteristik Matematika dalam Pencapaian Tujuan Mata pelajaran Matematika di SMP/MTs. Yogyakarta: Departemen Pendidikan Nasional PPPPTK.

Zarkasyi, A.S. (2005). Gontor dan Pembaharuan Pendidikan Pesantren. Jakarta: PT. Raja Grafindo Persada. 
